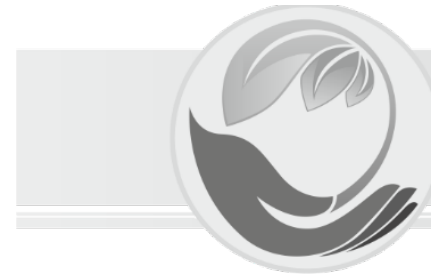

УДК 635.36:635.07
Інтенсивні та екологічно ощадні технології рослинництва Intensive and ecosaving techniques in crop production

\title{
Врожайність капусти брюссельської залежно від погодних умов вегетаційного періоду, схеми розміщення і строків вершкування рослин
}

\author{
Л.М. Пузік ${ }^{1}$, В.К. Пузік ${ }^{2}$, В.А. Бондаренко ${ }^{3}$ \\ Харківський національний технічний університет сільського господарства \\ ім. Петра Василенка (м. Харків, Україна) \\ e-mail:1/udapusik@gmail.com, ${ }^{2}$ kysmish@gmail.com, ${ }^{3}$ zim-hot@rambler.ru
}

\begin{abstract}
Проведені дослідження ставили за мету наукове обґрунтування впливу погодних умов вегетаційного періоду капусти брюссельської, схеми розміщення рослин, строків вершкування на врожайність. Польовий, фізико-хімічний, розрахунковий, аналізування. Умови вегетаційного періоду вплинули на формування врожайності капусти брюссельської. Розроблено рівняння регресійної залежності урожайності капусти брюссельської залежно від погодних умов вегетаційного періоду. Установлено, що продуктивність однієї рослини капусти брюссельської залежить від густоти рослин. Найбільшою (0,8 кг) вона була при густоті 35,7 тис. шт./га, меншою (0,5 кг) - при густоті 47,6 тис. шт./га. Залежно від строків вершкування цей показник в значній мірі зменшувався при більш пізньому проведенні цього прийому - від 0,7 до 0,2 г. Усе це в подальшому відобразилося на рівні врожайності качанчиків на відповідних варіантах. Урожайність капусти брюссельської залежить від кількості качанчиків і середньої маси. Кількість качанчиків коливається від 60 шт. Брілліант F1 до 66 шт. Абакус F1. Але середня маса качанчика гібрида Брілліант F1 перевищувала середню масу качанчика Абакуса F1 в 2,5 раза, що суттєво вплинуло на загальну врожайність капусти. Встановлено підвищення врожайності - на 0,6 т/га при загущенні від 28,6 до 35,7 тис. шт./га. Подальше загущення до 47,6 тис. шт./га призвело до зменшення рівня врожайності на 1,1 т/га порівняно з густотою 28,6 тис. шт./га. Вважати третю декаду серпня оптимальним строком вершкування капусти брюссельської. Запізнення з вершкуванням призвело до зниження врожайності на 3,1 т/га, а повна відмова від цього прийому - на 4,7 т/га при HIP05 = 0,91 т/га. Урожайність капусти брюссельської має тісний зв'язок з масою качанчиків: $r=0,72 \pm 0,03 \ldots 0,77 \pm 0,03$ залежно від гібрида. Кількість качанчиків на рослині мала сильний зв'язок з урожайністю гібрида Абакус F1: $r=0,85 \pm 0,02$, у Брілліанта F1 - слабкий.
\end{abstract}

Ключові слова: Капуста брюссельська, погодні умови, площа живлення, схема розміщення рослин, вершкування рослин.

Вступ. Овочі родини Капустяних мають високу врожайність, транспортабельні, стійкі до понижених температур, майже всі відрізняються доброю лежкістю при зберіганні. Капуста містить велику кількість вуглеводів, легкозасвоюваних повноцінних білків, мінеральних солей, комплекс вітамінів, органічні кислоти, гормональні речовини, накопичує багато солей калію, ферменти. Більш цінними з видів капусти $є$ брюссельська та броколі. [1, 2]. Цьому сприяє хімічний склад цих видів капусти, що обумовлює їхню безумовну дієтичну цінність.

Важливу роль при вирощуванні всіх сільськогосподарських рослин, у тому числі капусти брюссельської, відіграють схеми сівби і густота рослин [3]. Забезпечення оптимальної густоти рослин на кожному гектарі посіву $є$ однією з важливих умов збільшення врожаю овочевих рослин при добрій якості продуктових органів [4]. У своїх дослідженнях В.І. Нагорний спостерігав залежність між передзбиральною густотою і величиною врожаю. Він дійшов висновку, що в більшості випадків оптимальна густота посіву, умови ії фрормування і для максимального виходу врожаю найкращої якості для більшості сільськогосподарських культур досі не встановлені, і тому пропонує продовжувати експериментальні пошуки в цьому напрямку [5]. 
Господарсько-біологічну оцінку сортів і прийоми вирощування в лісостеповій зоні в Київській області проводила І.М Срібна. Вона вважає, що схеми посадки капусти брюссельської середньопізніх та пізніх сортів - 0,7 х 0,5 м при густоті 28,6 тис. шт./га. Для отримання кращого врожаю пізньостиглі сорти рекомендовано прищипувати 10 вересня, а у середньопізніх сортів цей прийом застосовувати недоцільно [6 - 8].

Одне 3 корінних питань вирощування будьякої сільськогосподарської рослини - вибір площі живлення [9]. Оптимізація її є головним фактором, який обумовлює отримання того чи іншого розміру продуктового органа. Родючість ґрунту має важливе значення при встановленні площі живлення овочевих рослин. Існує багато різних поглядів щодо цього. Одні автори вважають, що чим родючішим $€$ ґрунт, тим більшими повинні бути площі живлення. Інші автори рекомендують зменшувати площу живлення при підвищенні родючості ґрунту [10]. При несприятливих умовах росту і розвитку рослин, незалежно від того, викликане це недостачею чи надлишком якихось факторів, площа живлення повинна бути більшою, ніж при найбільш правильному для даних конкретних умов їх співвідношенні.

Не останню роль при визначенні площі живлення рослин, в тому числі й капусти брюссельської, відіграє ступінь їх забезпечення ґрунтовою вологою. Якщо існує загроза в нестачі вологи, то потрібно зменшити кількість рослин на даній площі, або, на думку К.А Тимірязєва треба рідше сіяти. Але слід зауважити, що в посушливих для рослин умовах важлива не абсолютна кількість води в ґрунті, а кількість її в прикореневому шарі, тобто ступінь насичення ґрунту вологою [5]. Науковець В.І. Іванівська стверджує, що при зрошенні рослини краще використовують поживні речовини, у зв'язку з чим посіви повинні бути більш загущеними. Використовуючи оптимальні площі живлення різних сортів та видів рослин можливо без витрат підняти врожайність на 30-40 $\%$ та більше [11].

Особливістю вирощування капусти брюссельської $\epsilon$ те, що не пізніше як за 20 діб, а в основному за 1-1,5 місяці (наприкінці серпня - у вересні) до збирання врожаю проводять вершкування при досягненні нижніми головками 1,3-1,5 см в діаметрі (прищипують верхівкову бруньку), що сприяє росту і формуванню більш щільних головок. Врожайність досягає 6-13 т/га [10, 12].

В Україні питання щодо оптимальної густоти рослин капусти брюссельської, а також строків її вершкування не можна вважати досконало вирішеним. Воно вимагає подальшої розробки відносно різних ґрунтово-кліматичних зон, нових високопродуктивних сортів і гібридів (в тому числі іноземної селекції), способів зрошення та інших умов овочівництва.

\section{Матеріали та методи дослідження}

Дослідження проведені на базі науково-навчально-виробничого центру „Краплинне зрошення” кафедри плодоовочівництва і зберігання Харківського національного аграрного університету ім. В.В. Докучаєва. У дослідах при вирощуванні брюссельської капусти попередником були пасльонові - картопля, томат, перець, після збирання яких проводили лущення в два сліди і оранку на глибину 20-22 см. Передсадивний обробіток ґрунту полягав в ранньовесняному боронуванні та двох культиваціях на глибину 10-12 см. Розсаду вирощували касетним способом. Висаджували розсаду вручну в нарізані борозни у фазу 4-5-ти справжніх листків стрічковим способом за схемами $(40+100)$ x $50 \mathrm{~cm},(40+100)$ x $40 \mathrm{i}$ $(40+100)$ x 30 см згідно зі схемою досліду 25травня, 3 липня та 19 червня, на глибину 6-8 см, щоб не присипати точку росту. Перед висадкою борозни заливали водою з розрахунку 0,2-0,5 л на рослину. Догляд за рослинами полягав в ручних прополюваннях (провели 3 ручні прополки), поливах краплинним зрошуванням (провели 7-8 поливів нормою 100-150 м³/га) і захисті рослин від шкідників (провели 5-6 обприскувань проти капустяної блішки і гусені капустяного білана препаратами Актара, Моспілан, Енжіо, Матч). За 30 діб до збирання провели “вершкування" - видалення центральної (верхівкової) бруньки для того щоб припинити ріст рослин і спровокувати формування продуктових органів - качанчиків. Збирання і облік врожаю проводили поділяночно вручну в другій декаді жовтня.

\section{Результати досліджень і обговорення}

Продуктивність однієї рослини капусти брюссельської гібрида Абакус $\mathrm{F}_{1}$ у 2014 р. залежно від густоти рослин становила від 0,5 до 0,8 кг (рис. 1). Найбільшою $(0,8$ кг) вона була при густоті 35,7 тис. шт./га, меншою $(0,5$ кг) - при густоті

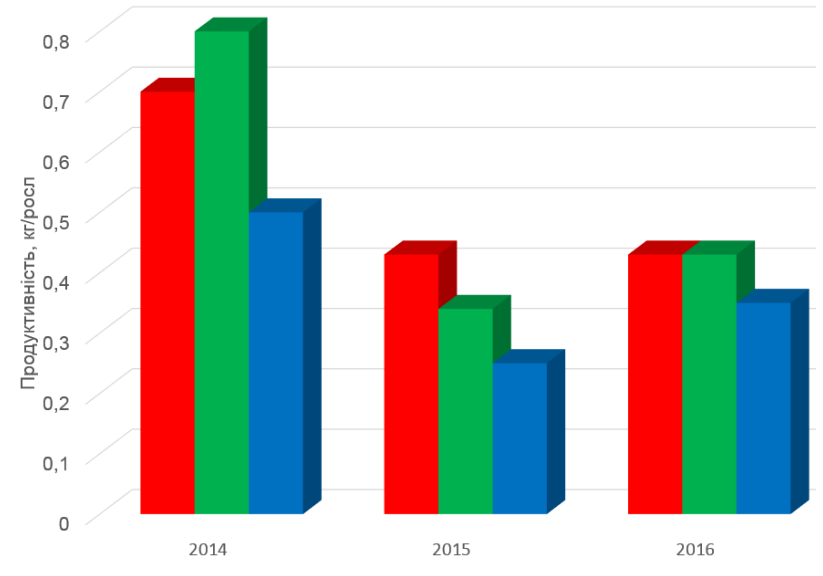

Рис. 1. Продуктивність капусти брюссельської залежно від густоти рослин, кг/ росл.:

- 28.6 тис. шт./га; $\square-35.7$ тис. шт./га; $\square-47.6$ тис. шт./га. 
47,6 тис. шт./га. Залежно від строків вершкування цей показник в значній мірі зменшувався при більш пізньому проведенні цього прийому - від 0,7 до 0,2 г (рис. 2).

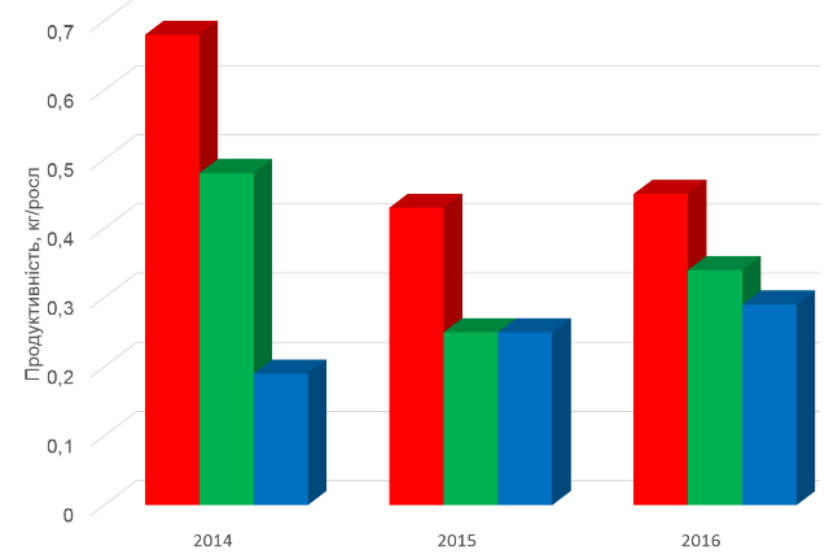

Рис. 2. Продуктивність капусти брюссельської залежно від строків вершкування, кг/ росл.:

$\square$ - 3 декада серпня; $\square$ - 3 декада вересня; $\square$ - без вершкування.

Усе це в подальшому відобразилося на рівні врожайності качанчиків на відповідних варіантах. В умовах 2014 р. врожайність капусти брюссельської гібрида Абакус $\mathrm{F}_{1}$ при контрольній густоті 28,6 тис. шт./га (схема розміщення рослин (40+100)x50 см) становила 15,5 т/га (табл.1).

Збільшення кількості рослин на гектарі до 35,7 тис. шт. забезпечило підвищення рівня врожайності з 15,5 до 16,7 т/га. Але це підвищення не можна вважати достовірним при $\mathrm{HIP}_{05}=1,27$ т/га $(8,13 \%)$.

Тому вважаємо, що у 20014 р. врожайність качанчиків капусти брюссельської гібрида Абакус $\mathrm{F}_{1}$ при густоті 35,7 тис. шт./га була в межах помилки досліду порівняно з урожайністю на густоті 28,6 тис. шт./га. Подальше загущення до 47,6 тис. шт. / га достовірно знизило врожайність порівняно як з густотою 28,6 тис. шт./га (на 1,8 т/га), так і з густотою 35,7 тис. шт. / га (на 3,0 т/га) при $\mathrm{HIP}_{05}=1,27$ т/га.

В умовах 2015 р. врожайність капусти брюссельської знаходилась в межах від 12,3 до 14,7 т/га при $\mathrm{HIP}_{05}=1,72$ т/га, або 13,67 \%. Продуктивність однієї рослини капусти брюссельської гібрида Абакус $\mathrm{F}_{1}$ у 2008 році залежно від густоти рослин становила від 0,251 до 0,444 кг. Найбільшою $(0,444$ кг) вона була при густоті 28,6 тис. шт./га, найменшою $(0,251$ кг) - при густоті 47,6 тис. шт./га.

Залежно від строків вершкування цей показник значно зменшувався у разі більш пізнього проведення цього прийому - від 0,444 до 0,257 кг у
2015 р. та від 0,457 до 0,295 кг (див. рис. 2). Усе це в подальшому відобразилось на рівні врожайності качанчиків на відповідних варіантах.

У 2016 р. врожайність капусти брюссельської була в таких межах - від 11,0 до 12,4 т/га при $\mathrm{HIP}_{05}=3,5$ т /га, або $28,86 \%$.

Продуктивність однієї рослини капусти брюссельської в умовах 2016 р. залежно від густоти рослин становила від 0,383 до 0,457 кг (див. рис. 1.). Найбільшою продуктивність була при густоті 28,6 тис.шт./га і становила 0,457 кг, а найменшою - відповідно при густоті 47,6 тис. шт./га - 0,383 кг.

У середньому за 2014-2016 рр. нами було встановлено незначне підвищення врожайності на 0,6 т/га при загущенні від 28,6 до 35,7 тис. шт./га. Подальше загущення до 47,6 тис. шт./га призвело до зменшення рівня врожайності на 1,1 т/га порівняно 3 густотою 28,6 тис. шт./га.

Таблиця 1. Урожайність капусти брюссельської гібрида Абакус F1 залежно від схеми розміщення і густоти рослин, т/га (20014-2016рр.)

\begin{tabular}{|c|c|c|c|c|c|}
\hline \multirow[b]{2}{*}{$\begin{array}{c}\text { Схема } \\
\text { розміщення, } \\
\text { см }\end{array}$} & \multicolumn{5}{|c|}{ Урожайність, т/га } \\
\hline & $\frac{\dot{2}}{ \pm}$ & $\frac{\dot{0}}{\stackrel{0}{0}}$ & $\frac{\dot{0}}{0}$ & 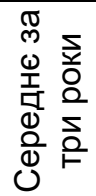 & $\begin{aligned} & \text { 옴 } \\
& \text { 음 } \\
& \text { 을 } \\
&+1 \\
&+1 \\
& \text { 동 }\end{aligned}$ \\
\hline$(40+100) \times 50$ & 15,5 & 12,7 & 11,0 & 13,1 & - \\
\hline$(40+100) \times 40$ & 16,7 & 12,7 & 11,7 & 13,7 & 0,6 \\
\hline$(40+100) \times 30$ & 13,7 & 12,3 & 12,4 & 12,8 & $-1,1$ \\
\hline $\mathrm{HIP}_{05}, \mathrm{~T} / \mathrm{ra}$ & 1,27 & 1,72 & & & - \\
\hline
\end{tabular}

Подібні результати були одержані при дослідженні капусти білоголової. У середньому за три роки дослідження спостерігалася така сама закономірність, як і окремо за кожним роком. При загущенні від 28,6 до 47,6 тис. шт. / га маса однієї головки зменшується від 1,61 до 1,11 кг у сорту Харківська зимова, від 1,43 до 1,14 кг - у гібрида Куізор $F_{1}$, від 1,68 до 1,28 кг - у гібрида Ердено $\mathrm{F}_{1}$, від 2,38 до 1,80 кг - у гібрида Агресор $\mathrm{F}_{1}$, та від 0,71-0,52 кг - у гібрида Новатор $\mathrm{F}_{1}$.

При зменшенні маси однієї головки, але за рахунок збільшення кількості рослин на площі рівень врожайності при загущенні в середньому за три роки збільшився: від 49,2 до 57,9 т/га - у сорту Харківська зимова, від 44,1 до 60,7 т/га - у гібрида Куізор $\mathrm{F}_{1}$, від 50,3 до 63,7 т/га - у гібрида Ердено $F_{1}$, від 74,8 до 89,9 т/га - у гібрида Агреcop $\mathrm{F}_{1}$, та від 20,1 до 24,7 т/га - у гібрида Новатор $\mathrm{F}_{1}$. Залежно від сортів і гібридів в середньому за три роки відмічали незначну різницю у гібридів іноземної селекції порівняно з контрольним сортом Харківська зимова [13]. 
Таким чином, за отриманими у 2015-2016 рр. даними встановлено, що густота 28,6 тис. шт./га при схемі розміщення рослин $(40+100)$ x 50 см $€$ оптимальною густотою рослин капусти брюссельської.

На верхівці рослини капусти брюссельської формується розетка листків і якщо ії не обмежуватиме у рості, качанчики починаючи із середини стебла і до верхівки утворюються дрібними, що негативно впливає на урожайність та товарність продукції. Щоб запобігти цьому в промисловості застосовують вершкування - видалення верхівкової бруньки за 1-1,5 місяці до збирання врожаю. У наших дослідженнях вершкування позитивно впливало на масу качанчиків. У нижній частині стебла у гібрида Абакус $F_{1}$ упродовж років досліджень формувалися качанчики масою 5,07,5 г, у Брілліанта $F_{1}-8,5-19,7$, в середній частині маса качанчиків збільшилася у Абакуса $F_{1}$ до 6,3-8,8 г, у Брілліанта $F_{1}$ до 9,8-26,6 г; верхівкові качанчики були самими крупними, їх маса сягала у Абакуса $F_{1}$ до 8,5-15,0 г, у Брілліанта $F_{1}$ до 13,4-40,1 г. Слід відмітити, що збільшення маси качанчиків на стеблі рослин у Брілліанта $\mathrm{F}_{1}$ відбувалося плавно. У середньому за роки досліджень маса качанчиків з середньої частини стебла гібрида Абакус $F_{1}$ перевищувала масу качанчиків 3 нижньої в 1,3 раза, а качанчики з верхньої частини стебла мали масу в 1,5 раза більшу, ніж із середньої. У Брілліанта $F_{1}$ маса качанчиків з середньої частини стебла перевищувала масу качанчиків з нижньої частини в 1,4 раза; качанчики з верхньої частини стебла мали масу в 1,4 раза більшу, ніж качанчики з середньої частини.

Упродовж 2013-2016 рр. досліджень маса качанчики гібрида Абакус $F_{1}$ коливалася у межах 6,6-9,1 г, у Брілліанта $F_{1}-11,2-27,1$ г. За цим показником гібриди істотно $\left(\mathrm{HIP}_{05}=1,4\right.$ г) різнилися між собою. У середньому за роки досліджень середня маса качанчиків Абакуса $F_{1}$ була на рівні 8,0 г, у Брілліанта F1 в 2,4 раза більша: 19,2 г.

Урожайність капусти брюссельської залежить від кількості качанчиків і середньої маси. Кількість качанчиків коливається від 60 шт. Брілліант F1 до 66 шт. Абакус F1. Але середня маса качанчика гібрида Брілліант F1 перевищувала середню масу качанчика Абакуса F1 в 2,5 раза, що суттєво вплинуло на загальну врожайність капусти.

Науковець А. Лебедева установила, що кількість качанчиків на одній рослині капусти брюссельської коливається від 35-70 до 90 і більше штук, маса однієї головки 8-15 г, загальна їхня маса сягає 300-800 г. [14].

В умовах 2014 р. при проведенні вершкування в 3-й декаді серпня врожайність капусти брюссельської гібрида Абакус $F_{1}$ становила 15,5 т/га. Запізнення з проведенням цього важливого технологічного прийому на один місяць (вершкування в 3-й декаді вересня) призводить до суттєвого зниження рівня врожайності - до 12,8 т/га, тобто на 2,7 т/га (17,5 \%) при $\mathrm{HIP}_{05}=$
1,24 т/га (10,96 \%). Повна відмова від вершкування в цьому році набагато знизила врожайність - на 9,8 т/га, або на 63,2 \% (табл. 2).

У 2015 р. спостерігали таку саму закономірність. Запізнення з вершкуванням призводило до зниження рівня врожайності на 4,7 т/га, а повна відмова від цього прийому зменшила врожайність на 5,5 т/га при $\mathrm{HIP}_{05}=0,66$ т/га. Спостереження, які провели у 2016 р., підтвердили закономірність, яка була відмічена у 2014 - 2016 рр., відповідно запізнення з вершкуванням призвело до зниження врожайності на 3,1 т/га, а повна відмова від цього прийому - на 4,7 т/га при $\mathrm{HIP}_{05}=0,91 \mathrm{т} /$ га.

Таблиця 2. Урожайність капусти брюссельської гібрида Абакус F1 (Abacus F1) залежно від строків вершкування рослин, т/га

\begin{tabular}{|c|c|c|c|c|c|}
\hline \multirow[b]{2}{*}{ 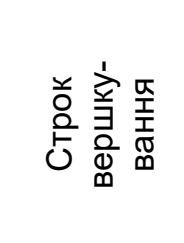 } & \multicolumn{5}{|c|}{ Урожайність, т/га } \\
\hline & $\frac{\dot{2}}{\dot{\Xi}}$ & $\frac{0}{\frac{0}{0}}$ & $\frac{\dot{e}}{\frac{0}{0}}$ & 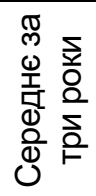 & 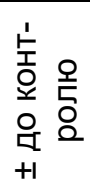 \\
\hline 3 дек. VIII & 15,5 & 15,5 & 13,1 & 13,7 & - \\
\hline 3 дек. IX & 12,8 & 12,8 & 10,0 & 10,3 & $-3,4$ \\
\hline $\begin{array}{l}\text { Без верш- } \\
\text { кування }\end{array}$ & 5,7 & 5,7 & 8,4 & 7,1 & $-6,6$ \\
\hline $\mathrm{HIP}_{05, \mathrm{~T} / г а}$ & 1,24 & 1,24 & 0,91 & - & - \\
\hline
\end{tabular}

Середні за 2014-2016 рр. дані повністю підтверджують результати, отримані нами окремо по кожному року.

Таким чином, вважаємо третю декаду серпня оптимальним строком вершкування капусти брюссельської. Запізнення з проведенням або повна відмова від цього прийому недопустима через різке зменшення рівня врожайності.

Урожайність овочевих рослин залежить від багатьох фракторів: умов вирощування, правильного догляду за рослинами, погодних умов, гібрида, сорту і т.д. Установлено, що врожайність капусти брюссельської за роки досліджень коливалась від 11,8 т/га до 44,5 т/га залежно від гібрида, і мала суттєву різницю (НIP05 0,8 - 7,7 т/га). Погодні умови вегетаційного періоду вносили суттєві корективи у фрормування врожаю капусти брюссельської. Було встановлено, що різні гібриди неоднаково реагують на погодні умови вегетаційного періоду. Під час вирощування капусти брюссельської гібрида Абакус F1 погодні умови 2016р. були більш сприятливі, ніж для гібрида Брілліант F1. Урожайність гібрида Абакус F1 становила 16,6 т/га, що перевищувало цей показник 2014 -2015pр. на 0,5 - 4,8 т/га відповідно. Тоді як для гібрида Брілліант F1 сприятливіші умови для формування врожаю були у 2014 р. коли врожайність 
становила 44,5 т/га, і перевищувала урожайність капусти брюссельської 2015 - 2016 рр. на 9,9 - 23,7 т/га.

Отже, розбіжність урожайності капусти брюссельської можна пояснити тим, що різні гібриди неоднаково реагують на погодні умови вегетаційного періоду. Для гібрида Брілліант F1 найкращими умовами росту і розвитку рослин є підвищена температура повітря що спостерігалась у 2014p. При цьому була одержана найбільша урожайність - 44,5 т/га, тоді як для гібрида Абакус F1 цей вегетаційний період негативно вплинув на врожайність, яка становила 11,8 т/га, що на 0,54,8 т/га менше ніж в інші роки. У 2016 р. спостерігалась велика кількість опадів, що зменшило врожайність гібрида Брілліант на 10,1 - 23,7 т/га. Навпаки, підвищена кількість опадів позитивно вплинула на врожайність гібрида Абакус F1, яка становила 16,6 т/га що на 0,5-4,8 т/га вище порівняно з іншими роками.

За роки досліджень гібрид Брілліант $\mathrm{F}_{1}$ форомував істотно вищу (НIP05 = 3,1 т/га) урожайність, ніж Абакус $\mathrm{F}_{1}$. У середньому за роки досліджень урожайність Брілліанта $\mathrm{F}_{1}$ на 55 \% перевищувала показник Абакуса $F_{1}$ і становила 36,3 т/га. Але за її стабільністю він поступався гібриду Абакус $\mathrm{F}_{1}$ : коефіцієнт фенотипової стабільності Левіса врожайності Брілліанта $\mathrm{F}_{1}$ за роки досліджень становив 2,2, Абакуса $F_{1}-1,7$. Коефіцієнт агрономічної стабільності вище 70 \% був також в Абакуса $F_{1}-78,5$ \%. Дисперсійним аналізом встановлено, що урожайність капусти брюссельської і продуктивність однієї рослини, на $65 \%$ залежали від особливостей гібрида (фактор A) і на $20 \%$ від умов вегетаційного періоду (фактор В). Сукупна дія фракторів АВ складала $14 \%$, частка інших фракторів становила $1 \%$ (рис. 3).

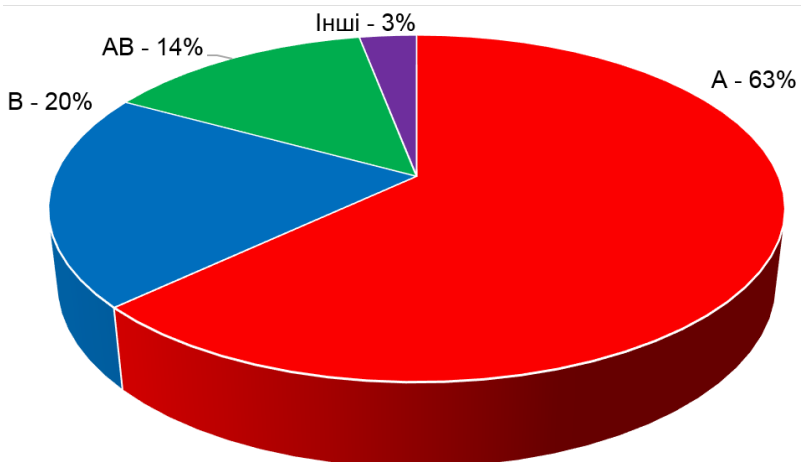

Рис. 3. Вплив факторів, що вивчалися, на формування врожайності капусти брюссельської (2014-2016 рр.):

А - особливість гібрида: $\square$ В - умови вегетаційного періоду; $\square$ AB - сумісна для факторів; $\square$ - інші фактори.
Кореляційним аналізом встановлено, що урожайність капусти брюссельської мала тісний зв'язок з масою головки:

$$
r=0,72 \pm 0,03 \ldots 0,77 \pm 0,03
$$

залежно від гібрида. Кількість головок на рослині мала сильний зв'язок з урожайністю гібрида Абакус $F 1: r=0,85 \pm 0,02$, у Брілліанта $F 1$ - слабкий.

Установлено, що дослідні гібриди неоднаково реагують на фактори, що впливають на їхню урожайність (табл. 3).

Таблиця 3. Кореляційна залежність урожайності гібридів капусти брюссельської від умов вегетаційного періоду

\begin{tabular}{|c|c|c|c|c|}
\hline 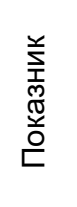 & Гібрид & 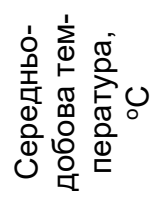 & 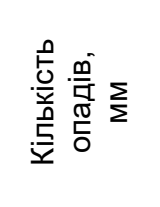 & 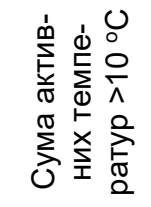 \\
\hline \multirow{2}{*}{ 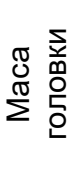 } & $\begin{array}{c}\text { Абакус } \\
\mathrm{F}_{1}\end{array}$ & $\begin{array}{c}r= \\
0,76 \pm 0,03\end{array}$ & $\begin{array}{c}r= \\
-0,27 \pm 0,08\end{array}$ & $\begin{array}{c}r= \\
0,81 \pm 0,02\end{array}$ \\
\hline & $\begin{array}{l}\text { Бріллі- } \\
\text { ант F1 }\end{array}$ & $\begin{array}{c}r= \\
0,45 \pm 0,06\end{array}$ & $\begin{array}{c}r= \\
-0,52 \pm 0,05\end{array}$ & $\begin{array}{c}r= \\
0,79 \pm 0,03\end{array}$ \\
\hline \multirow{2}{*}{ 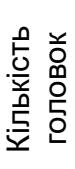 } & $\begin{array}{c}\text { Абакус } \\
F_{1}\end{array}$ & $\begin{array}{c}r= \\
-0,40 \pm 0,06\end{array}$ & $\begin{array}{c}r= \\
0,84 \pm 0,02\end{array}$ & $\begin{array}{c}r= \\
-0,33 \pm 0,07\end{array}$ \\
\hline & $\begin{array}{l}\text { Бріллі- } \\
\text { ант F1 }\end{array}$ & $\begin{array}{c}r= \\
-0,42 \pm 0,06\end{array}$ & $\begin{array}{c}r= \\
0,86 \pm 0,02\end{array}$ & $\begin{array}{c}r= \\
-0,21 \pm 0,08\end{array}$ \\
\hline \multirow{2}{*}{ 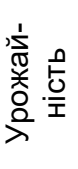 } & $\begin{array}{c}\text { Абакус } \\
\text { F1 }\end{array}$ & $\begin{array}{c}r= \\
0,14 \pm 0,09\end{array}$ & $\begin{array}{c}r= \\
0,45 \pm 0,06\end{array}$ & $\begin{array}{c}r= \\
0,21 \pm 0,08\end{array}$ \\
\hline & $\begin{array}{l}\text { Бріллі- } \\
\text { ант F1 }\end{array}$ & $\begin{array}{c}r= \\
0,14 \pm 0,09\end{array}$ & $\begin{array}{c}r= \\
0,57 \pm 0,05\end{array}$ & $\begin{array}{c}r= \\
0,63 \pm 0,04\end{array}$ \\
\hline
\end{tabular}

На основі отриманих даних урожайність капусти брюссельської більшою мірою залежить від середньодобової температури (х1), суми опадів (x2) та суми активних температур (x3) вегетаційного періоду. Тому рівняння регресії для прогнозування врожайності гібрида Абакус F1 має вигляд:

$$
y=-179,97+8,51 x 1+0,095 x 2-0,001 x 3 .
$$

Рівняння регресії для урожайності гібрида Брілліант F1 має вигляд:

$$
\mathrm{y}=144,63-21,78 \mathrm{x} 1+0,041 \mathrm{x} 2+0,11 \mathrm{x} 3
$$

\section{Висновки .}

Встановлено підвищення врожайності - на 0,6 т/га при загущенні від 28,6 до 35,7 тис. шт./га. Подальше загущення до 47,6 тис. шт./га призвело до зменшення рівня врожайності на 1,1 т/га порівняно з густотою 28,6 тис. шт./га. 
Вважати третю декаду серпня оптимальним строком вершкування капусти брюссельської. Запізнення з вершкуванням призвело до зниження врожайності на 3,1 т/га, а повна відмова від цього прийому - на 4,7 т/га при НIP05 = 0,91 т/га.

Урожайність капусти брюссельської має тісний зв'язок 3 масою качанчиків: $r=$ $0,72 \pm 0,03 \ldots 0,77 \pm 0,03$ залежно від гібрида. Кількість качанчиків на рослині мала сильний зв'язок з урожайністю гібрида Абакус $F 1: r=0,85 \pm 0,02$, у Брілліанта $F 1$ - слабкий.

\section{Література}

1. Кучеренко Т. Когда и большой урожай не в радость / Т. Кучеренко // Овощеводство. - К: ООО "Юнивест Медиа", 2012. - № 4 С. 70 - 75.

2. В Україні різко виріс попит на брокколі, цвітну і брюссельську капусту // Проект аграрного маркетингу [Електронний ресурс]. URL: http://www.agroua.net/news/news_8015.html (дата обращения: 08.02.2016).

3. Гіль Л. С., Пашковський А. І., Суліма Л. Т. Сучасні технології овочівництва закритого і відкритого ґрунту: навч. посібник. Ч. 2: Відкритий ґрунт. Вінниця: Нова Книга, 2008. 312 с.

4. Болотских А. С. Капуста. Харьков: Фолио, 2002. 320 c.

5. Нагорний В.І. Густота посіву як фактор підвищення продуктивності сільськогосподарських культур / В.І. Нагорний // Вісн. СДАУ. - Сер. Агрохімія і біологія. - Суми, 2001. - Вип. 5. - С. 81 - 83.

6. Жук О.Я. Продуктивність пізньостиглих сортів капусти брюссельської в умовах Лісостепу / О.Я. Жук, І.М. Срібна //Овочівництво і баштанництво. - Х., - 2004. №49. - С. 268 - 274.

7. Жук О.Я. Вплив строків прищипування рослин на формування головочок та врожайності капусти брюссельської/О.Я. Жук, І.М. Срібна //Наук. вісн. НАУ. - К., 2005. - №84. - С. 118 - 122.

8. Срібна І.М. Вплив схем розміщення рослин на врожайність капусти брюссельської /I.М. Срібна // Вісн. Білоцерк. держ. аграр. ун-ту. - Біла Церква, 2006. - Вип. 35. - С. 122 - 126.

9. Срібна І.М. Господарсько-біологічна оцінка сортів і прийомів вирощування капусти брюссельської в Лісостепу України /І.М. Срібна під ред.. О.Я.Жука. - К.: НАУ, 2006. - 21 с.

10. Барабаш О. Ю., Гутиря С. Т. Капустяні культури. Київ: Вища шк., 2006. 93 с.

11. Эдельштейн В.И. Овощеводство /В.И. Эдельштейн - М.: Сельхозгиз, 1962. - 440 с.

12. Жук О. Я., Сидорова І. М., Федосій І. О. Капуста брюссельська: монографрія. Київ: НіланЛТД, 2013. 178 c,

13. Мулярчук О.І. Врожайність сортів капусти білоголової залежно від впливу елементів технології вирощування / О.І. Мулярчук // Селекція і насінництво. Міжвідомчий науковий збірник. Інститут рослинництва УААН ім. В.Я. Юр'єва. 2009. - Вип.. 97. - С. 260 - 266.

14. Лебедева А. Капуста брюссельская // Наша усадьба. 2001. №3. С. 9.

\section{References}

1. Kucherenko, T. (2012) 'Kohda y bol'shoy urozhay ne v radost", Ovoshchevodstvo, (4), pp. 70 - 75.

2. V Ukrayini rizko vyris popyt na brokoli, tsvitnu ta bryussel's'ku kapustu (2005) Ahrarnyy sektor Ukrayiny. Available at: http://www.agroua.net/news /news_8015.html (Accessed: 8 February 2016).

3. Hil' L. S., Pashkovs'kyy A. I., Sulima L. T. Suchasni tekhnolohiyi ovochivnytstva zakrytoho i vidkrytoho gruntu: navch. posibnyk. CH. 2: Vidkrytyy grunt. Vinnytsya: Nova Knyha, 2008. 312 p.

4. Bolotskikh A. S. Kapusta. Khar'kov: Folio, 2002. 320 p.

5. Nahornyy V.I. Hustota posivu yak faktor pidvyshchennya produktyvnosti sil's'kohospodars'kykh kul'tur // Visn. SDAU. - Ser. Ahrokhimiya i biolohiya. - Sumy, 2001. - Vyp.. 5. - P. 81-83.

6. Zhuk O.YA., I.M. Sribna Produktyvnist' pizn'ostyhlykh sortiv kapusty bryussel's'koyi v umovakh Lisostepu //Ovochivnytstvo i bashtannytstvo. - KH., - 2004. №49. - P. $268-274$.

7. Zhuk O.YA., I.M. Sribna. Vplyv strokiv pryshchypuvannya roslyn na formuvannya holovochok ta vrozhaynosti kapusty bryussel's'koyi // Nauk. visn. NAU. - K., 2005. - №84. - P. 118 - 122.

8. Sribna I.M. Vplyv skhem rozmishchennya roslyn na vrozhaynist' kapusty bryussel's'koyi //Visn. Bilotserk. derzh. ahrar. un-tu. - Bila Tserkva, 2006. - Vyp.. 35. - P. 122 - 126.

9. Sribna I.M. Hospodars'ko-biolohichna otsinka sortiv i pryyomiv vyroshchuvannya kapusty bryussel's'koyi v Lisostepu Ukrayiny pid red. O.YA. Zhuka. - K.: NAU, 2006. - 21 p.

10. Barabash O. YU., Hutyrya S. T. Kapustyani kul'tury. Kyyiv: Vyshcha shk., 2006. 93 p.

11. Edel'shteyn V.I. Ovoshchevodstvo. M.: Sel'khozgiz, 1962. - $440 \mathrm{p}$.

12. Zhuk O. YA., Sydorova I. M., Fedosiy I. O. Kapusta bryussel's'ka: monohrafiya. Kyyiv: NilanLTD, 2013. 178 p.

13. Mulyarchuk O.I. Vrozhaynist' sortiv kapusty biloholovoyi zalezhno vid vplyvu elementiv tekhnolohiyi vyroshchuvannya // Selektsiya i nasinnytstvo. Mizhvidomchyy naukovyy zbirnyk. Instytut roslynnytstva UAAN im. V.YA. Yur"yeva. - 2009. - Vyp.. 97. - P. 260266.

14. Lebedeva A. Kapusta bryussel'skaya // Nasha usad'ba. 2001. №3. P. 9. 


\section{Аннотация}

\section{Урожайность капусты брюссельской в зависимости от погодных условий вегетационного периода, схемы размещения и сроков вершкования растений}

\section{Л. М. Пузик, В. К. Пузик, В. А. Бондаренко}

Проведенные исследования ставили своей целью научное обоснование влияния погодных условий вегетационного периода капусты брюссельской, схемы размещения растений, сроков вершкования на урожайность. Полевой, физико-химический, расчетный, анализ. Условия вегетационного периода повлияли на формирование урожайности капусты брюссельской. Разработаны уравнения регрессионной зависимости урожайности капусты брюссельской в зависимости от погодных условий вегетационного периода. Установлено, что продуктивность одного растения капусты брюссельской зависит от густоты растений. Наибольшей (0,8 кг) она была при густоте 35,7 тыс. шт. / га, меньше (0,5 кг) - при плотности 47,6 тыс. шт. / га. В зависимости от сроков вершкования этот показатель в значительной степени уменьшался при более позднем проведении этого приема - от 0,7 до 0,2 г. Все это в дальнейшем отразилось на уровне урожайности головок на соответствующих вариантах. Урожайность капусты брюссельской зависит от количества кочанчиков и средней массы. Количество головок колеблется от 60 шт. Бриллиант F1 до 66 шт. Абакус F1. Но средняя масса головки гибрида Бриллиант F1 превышала среднюю массу головки Абакус F1 в 2,5 раза, что существенно повлияло на общую урожайность капусты. Установлено повышение урожайности - на 0,6 т/га при загущении от 28,6 до 35,7 тыс. шт. / га. Дальнейшее сгущение до 47,6 тыс. шт. / га привело к уменьшению уровня урожайности на 1,1 т/га по сравнению с плотностью 28,6 тыс. шт. / га. Считать третью декаду августа оптимальным сроком вершкования капусты брюссельской. Опоздание с вершкованиям привело к снижению урожайности на 3,1 т/га, а полный отказ от этого приема - на 4,7 т/га при НИР05 = 0,91 т/га. Урожайность капусты брюссельской имеет тесную связь с массой головки: $r=0,72 \pm 0,03 \ldots 0,77 \pm 0,03$ в зависимости от гибрида. Количество головок на растении имела сильную связь с урожайностью гибрида Абакус F1: r = 0,85 \pm 0,02, в бриллиант F1 - слабый.

Ключевые слова: Капуста брюссельская, погодные условия, площадь питания, схема размещения растений, вершкования растений.

\section{Abstract \\ The yield of Brussels cabbage depending on the weather conditions of the growing season, the layout of the placement and the terms of the maintenance of plants}

\section{M. Pusik, V. K. Pusik, V. A. Bondarenko}

The researches were aimed at a scientific substantiation of the influence of the weather conditions of the growing season of Brussels cabbage, the scheme of placement of plants, the terms of recipe for yield. Methods. Field, physico-chemical, calculation, analysis. Results The conditions of the growing season influenced the production of cabbage in Brussels. The equations of the regression dependence of the cabbage productivity of Brussels on the weather conditions of the vegetation period are developed It has been established that the productivity of a single Brusselsian cabbage plant depends on the density of plants. The largest $(0,8 \mathrm{~kg})$ she was with a density of 35,7 thousand pcs / ha, less $(0,5 \mathrm{~kg})$ - at a density of 47,6 thousand pcs/ha Depending on the terms of creaming, this indicator decreased to a great extent at a later date, from 0,7 to $0,2 \mathrm{~g}$. All this was reflected in the level of yield of the heads in the corresponding variants. The yield of Brussels sprouts depends on the number of cabbage and average weight. The number of heads varies from 60 pcs. Diamond F1 up to 66 pcs. Abacus F1. But the average weight of the hybrid head Diamond F1 exceeded the average weight of the Abacus F1 head 2,5 times, which significantly affected the total yield of cabbage. Conclusions Increase in productivity was established - by $0,6 \mathrm{t} /$ ha with a thickening from 28,6 to 35,7 ths. pcs / ha Further consolidation to 47,6 ths. pcs / ha resulted in a decrease in the yield level by $1,1 \mathrm{t} / \mathrm{ha}$ compared with a density of 28,6 ths. pcs / ha Consider the third decade of August as the optimum time for treating Brussels cabbage. Late with creaming reduced yields by $3,1 \mathrm{t} / \mathrm{ha}$, and the total refusal of this admission was $4,7 \mathrm{t} / \mathrm{ha}$ with LSD $05=0,91 \mathrm{t} / \mathrm{ha}$. The yield of Brussels sprouts is closely related to the weight of the head: $r=0,72 \pm 0,03 \ldots$ $0,77 \pm 0,03$ depending on the hybrid. The number of heads on the plant had a strong correlation with the yield of the hybrid Abakus F1: $r=0.85 \pm 0,02$, in the diamond F1 - weak.

Keywords: Brussels cabbage, weather conditions, food area, arrangement of plants, plant peeling

Бібліографрічне посилання/ Bibliography citation: Harvard

Pusik, L. M., Pusik, V. K. and Bondarenko, V. A. (2019) 'The yield of Brussels cabbage depending on the weather conditions of the growing season, the layout of the placement and the terms of the maintenance of plants', Engineering of nature management, 3(13), pp. $49-55$.

Подано до редакції / Received: 03.06.2019 